\title{
Comparative phytochemical evaluation, antimicrobial and antioxidant properties of Pleurotus ostreatus
}

\author{
Iwalokun, B. A. ${ }^{1}$, Usen, U. A ${ }^{1}$, Otunba, A. A. ${ }^{2}$ and Olukoya, D. K. ${ }^{2}$ \\ ${ }^{1}$ Departmernt of Biochemistry, Lagos state University, P. M. B 1087, Apapa Lagos, Nigeria. \\ ${ }^{2}$ DANIFOL Biotechnology Consult, Lagos, Nigeria.
}

Accepted 31 May, 2007

\begin{abstract}
This study scientifically examined the phytochemistry, antioxidant and antimicrobial potencies of two organic extracts of Pleurotus ostreatus. Generally, both extracts were effective against $89.8 \%$ of the isolates tested with Bacillus subtilis $(7.6-7.8 \mathrm{~mm})$, Escherichia coli $(7.6-8.2 \mathrm{~mm})$ and Saccharomycee cerevisae $(10.5-10.8 \mathrm{~mm})$ exhibiting highest gram $\pm v e$, gram -ve and fungal susceptibilities by agar well diffusion method, respectively. However, petroleum ether extract (PE) exhibited greater anti-gram negative bacterial activity than the acetone extract $(A E)$ and further produced growth inhibition of these isolates in broth. Compared to PE, the acetone extract elicited higher total phenolic content and in vitro antioxidant capacity. Phytochemical analyses of the extracts revealed low to moderate levels of terpenoids, tannins, steroidal glycosides and carbohydrates, while flavonoids, alkaloids and cynogenic glycosides were not detected. The results indicate that $P$. ostreatus possesses antimicrobial and antioxidant potentials.
\end{abstract}

Key words: Pleurotus ostreatus, organic extracts, antimicrobial activity, antioxidant capacity, phytochemistry.

\section{INTRODUCTION}

Edible mushrooms are nutritionally endowed fungi (mostly Basidiomycetes) that grow naturally on the trunks, leaves and roots of trees as well as decaying woody materials (Chang and Miles, 1992; Stamets, 2000; Lindequist et al., 2005). Scientific explorations of Shiitake mushrooms such as Lentinus edodes, Maitake mushrooms such as Grifola frondosa, chanterelles such as Chaterellus carius, white button mushrooms such as Agaricus bisporus, and oyster mushrooms have shown that they serve as repositories of B-vitamins such as niacin, flavin and pyridoxine (Solomko and Eliseeva, 1988); organic acids such as ascorbate, shikimate, malate and fumarate; carbohydrates such as the $\beta$-glucans; monoterpenoid and diterpenoid lipids; proteins such as hydrophobins and trace elements such as selenium (Dikeman et al., 2005; Valentao et al., 2005). These substances have been found through several in vitro and in vivo studies to be responsible for the antimicrobial, antioxidant, antitumor, antihypertensive and antiaging potentials of edible mush-

*Corresponding author. E-mail: bamwal@yahoo.com. Phone: 234-1-8504327. mushrooms (Lindequist et al., 2005). The recognition of Garnodema lucidium also called reshi as an antioxidant mushroom is due to its phenolic, terpenoids and polysaccharide polypeptide contents (Miller et al., 2000; Mau et al., 2002; Valentao et al., 2005). These bioactive compounds mediate biological activities including stimulation of interleukin-12 production, nitric oxide synthase activetion, free radical scavenging and iron chelating properties (Cui et al., 2005; Acharya et al., 2005).

Pleurotus ostreatus is among the edible mushrooms consumed in Nigeria. It is used as spice in vegetable soups and also fried to serve as meat (Annon, 2004). The mushroom is credited to be the third largest macrofungus cultivated for food and industial purposes worldwide. Nutritionally, the mushroom has been found to contain vitamins B1 (thiamin), B2 (riboflavin), B5 (niacin), B6 (pyridoxine and B7 (biotin) (Solomko and eliseeva, 1988).

The fruiting body of the mushroom is also a potential source of lignin and phenol degrading enzymes (Fountoulakis et al., 2002). While from clinical viewpoint, Bobeck and Galbavy (1999) showed that $P$. ostreatus elicited hypocholesterolemic and antherogenesis inhibition functions in rabbits and rat coutesy of its mycelial secretory products. 
However, unlike the fruiting bodies of few other edible mushrooms such as L. edodes, G. fondosa and G. Iucidium known for exhibiting antibacterial and antifungal activity in vitro, there is lack of information on the microbicidal properties of $P$. ostreatus coupled with inadequate data on its phytochemistry. It is hypothesized that knowledge of the phytoconsitituents of $P$. ostreatus would provide an insight into its biological functions beyond nutrition when consumed. In the present study, organic mycelia extracts of $P$. ostreatus were phytochemically analysed and tested for antioxidant function in vitro. The antimicrobial activity of these extracts was also examined.

\section{MATERIALS AND METHODS}

\section{Pleurotus ostreatus}

Strains of $P$. ostreatus sold as edible mushrooms in Lagos metropolis were brought at different locations in Lagos. They were identified at the Department of Pharmacognosy of the College of Medicine University of Lagos. A voucher specimen (PPL 001 - 002), was deposited in the Herbarium section at DANIFOL Biotechnology Consult Laboratory. The fruiting bodies, carefully removed from the hyphae were weighed then dried at $40^{\circ} \mathrm{C}$ for $24 \mathrm{~h}$. The dried fruiting body samples were weighed and ground into powder prior to extraction.

\section{Preparation of Pleurotus ostreatus extracts}

Dried samples of fruiting body powder ( $3.5 \mathrm{~g}$ each) were separately extracted with $100 \mathrm{ml}$ each of petroleum ether $\left(20-80^{\circ} \mathrm{C}\right)$ and $80 \%$ acetone for $2 \mathrm{~h}$ using soxhlet apparatus. The residual solvent was removed by evaporation at $40^{\circ} \mathrm{C}$ for $24 \mathrm{~h}$ in vacuo using a rotatory evaporator. The resulting organic extracts were further reconstituted to different concentrations $(0-100 \% \mathrm{v} / \mathrm{v})$ with $0.1 \%$ Tween-20 in phosphate buffered saline $(\mathrm{pH} 7.2)$ followed by storage in sterile capped bottles under refrigeration condition $\left(4^{\circ} \mathrm{C}\right)$ prior to use for subsequent assays.

\section{Phytochemical analysis of Pleurotus ostreatus extracts}

The phytoconstituents present in the organic extracts were determined qualitatively according to Sofowora (1993), Trease and Evans (1989) and Harbone (1973) as well as by thin layer chromatography (TLC). In TLC, the extracts spotted on silica coated plates, were developed using butanol-glacial acetic-water (100: 10 $: 10)$ as the solvent system. The developed plates were then sprayed with with vanillin solution (1\% (w/v) in $50 \%$ phosphoric acid) for steroid detection, Dragendorff's reagent for alkaloid detection and sodium metaperiodate $(0.1 \%)$ followed by ethanolic benzidine for glucose detection. Nicotinic acid, cholesterol D-glucose and tannic acid at $1 \%$ solution were prepared accordingly and used as standards in the TLC assay. The TLC results were further used to validate the presence of tannins based on positive reaction (brownish green - blue black coloration) with $0.1 \% \mathrm{FeCl}_{3}$, alkaloids based on positive reaction (brown coloration) with Dra-gendorff's reagent (Trease and Evans, 1989; Sofowora, 1993), steroids based on positive reactions (violet to blue or green) with acetic anhydride and $\mathrm{H}_{2} \mathrm{SO}_{4}$, steroidal glycosides by Keller-Killani test and cynogenic glycoside based red coloration of picrate paper (Harbone, 1973; Trease and Evans, 1993). The observation of persistent frothing in distilled water $(2 \mathrm{ml})$ by $1 \%$ standard saponin solution $(3 \mathrm{ml})$ follow- ed by formation of emulsion with olive oil $(0.5 \mathrm{ml})$ was used to indicate the presence of saponin in the extract (Trease and Evans, 1989).

\section{Total phenolic content determination}

The total phenolic compounds present in the extracts were determined spectrophotometrically at $750 \mathrm{~nm}$ as described by Lee et al. (2001) using Folin-Ciocalteau pheno reagent. Standard solutions of gallic acid $(20-200 \mathrm{mg} / \mathrm{ml})$ were used to prepare a standard curve. The total phenolic contents of the extracts are expressed in milligrams per ml of gallic equivalents (GAE) of triplicate measure-ments.

\section{Antioxidant activity determination}

The antioxidant activity of the $P$. ostreatus extracts was determined via the 2,2 - diphenylpicrylhydrazyl radical neutralization assay as described by Brand-Williams et al. (1995). Extracts were also tested as antioxidants using 2,2'-azino-bis(3-ethylbenzthiazoline-6-sulfonic acid (ABTS) assay (Cano et al., 1998). In both assays, $50 \mu \mathrm{l}$ of each extract was added to with $950 \mu \mathrm{l}$ of the free radical methanolic solution and stirred continuously for $15 \mathrm{~min}$ for $\mathrm{DPPH}$ or $10 \mathrm{~min}$ for ABTS. Decreases in absorbance were respectively measured at 414 and $515 \mathrm{~nm}$ for ABTS and DPPH systems, respectively, and compared to that of infusion made from green tea a well-known antioxidant food (Cao et al., 1996). The infusion was prepared by boiling $1 \mathrm{~g}$ green tea bag with $100 \mathrm{ml}$ of deionised water for $5 \mathrm{~min}$. Antioxidant activity of the each extract was expressed as vitamin C equivalent antioxidant capacity (VCEAC) in millimolar (mM) by extrapolation from the standard curve. Two - fold serial dilutions of Lascorbic acid (Aldrich, Germany) in deionised water to a final concentration range of $0.75-6.0 \mathrm{mM}$ were used to prepare the calibration curve.

\section{Microorganisms}

The microorganisms to which the antimicrobial properties of the organic extracts of $P$. ostreatus were tested were obtained from the Departents of Biotechnology and Molecular Biology of the Nigerian Institute of Medical Research (NIMR), Yaba-Lagos. The bacterial isolates were multidrug resistant determined by disc diffusion assay according to Iwalokun et al. (2004) (Table 1). They were recovered as viable isolates by subculturing their stock cultures in $16 \%$ glycerol-trypticase soy (TSB) or brain heart infusion broth $(\mathrm{BHI})$ at $-20^{\circ} \mathrm{C}$ or malt extraxt medium. The lactobacilli were recovered by growth in Mann Rogossa Sharpe (MRS) medium under anaerobic conditions (De Mann et al., 1960). Other bacterial isolates were recovered by growth on trypticase soy agar or blood agar under aerobic conditions at $37^{\circ} \mathrm{C}$ for $24 \mathrm{~h}$. Aerobic growth at $30^{\circ} \mathrm{C}$ for $24 \mathrm{~h}$ on potato dextrose agar (PDA) was the basis for the recovery of Saccharomyces cerevisiae and Candida isolates tested. The recovered microbes were gram stained to confirm their gram reaction status and speciated according to Cowan and Steel (1974). The gram-negative organisms include Escherichia coli, Salmonella typhi, Pseusomonas aeruginosa, Haemophillus influenza, while the gram-positive isolates were Bacillus licheniformis, Bacillus subtilis, Staphylococcus aureus, and Lactobacillus acidophilus

Strains of Candida albicans ATCC 1880 and Sacharomyces cerevisiae were also tested to validate the antibiotic and extract susceptibility assays of the fungal isolates tested.

\section{Antimicrobial testing of Pleurotus ostreatus extracts}

$P$. ostreatus extracts were tested for antimicrobial activity by agar well diffusion technique (Akpata and Akinrimisi, 1977) with a little 
Table 1. Bacterial isolates and antibiotic resistance profiles.

\begin{tabular}{|l|c|l|}
\hline${ }^{\circledR}$ Isolates & N & Antibiotic resistance \\
\hline Salmonella typhi & 5 & Cot, Col, Tet, Str, Chl, Amp \\
Staphyloccocus aureus & 8 & Str, Amp, Pen, Amo, Aug \\
Staphyloccocus epidermidis & 4 & Str, Amp, Amo, Pen \\
Staphyloccocus aureus & 2 & Str, Amp, Amo, Aug, Pen, Met \\
Escherichia coli & 10 & Cot, Col, Chl, Str, Tet \\
Haemophillus influenzae & 4 & Ery, Str, Cot, Amo, Amp, Tet \\
Proteus spp & 5 & Amp, Tet, Cot, Col, Str, Cot \\
Pseudomonas aeruginosa & 6 & Str, Ery, Tet, Kan, Col, Cot, Amo \\
Klebsiella pneumoniae & 4 & Amp, Tet, Str, TMP-STX \\
tLactobacillus acidophilus & 8 & Tet, Col \\
\hline
\end{tabular}

${ }^{\circledR}$ Isolates were grouped based on their display of $100 \%$ resistance to antibiotics by disk diffusion assay following identification according to Cowan and Steel (1974). N = number of isolates tested; Str = streptomycin; Ery = erythromycin; Aug = augmentin; Cef = cefotaxime; Cro = ceftriaxone; Tet = tetracycline; Amp = ampicillin; Amo = amoxycillin; Kan = kanamycin; Gen = gentamicin; $\mathrm{Chl}=$ chloramphenicol; $\mathrm{Col}=$ colistin sulphate; $\cot =$ cotrimoxazole; and TMP-STX = Trimetoprim - sulphamethoxazole. + The antibiotic resistance patterns of the isolates except $L$. acidophillus were given as previously described (Iwalokun et al, 2004).

modification. An overnight culture of each microbial isolate was emulsified with nutrient broth to a turbidity that was equivalent to $0.5 \mathrm{McF}$ arland $\left(10^{8} \mathrm{cfu} / \mathrm{ml}\right) .100 \mu \mathrm{l}$ of each standard inoculum was then streaked on nutrient agar and PDA at $10^{6} \mathrm{cfu} / \mathrm{ml}$ per spot to attain a confluent growth (Bauer et al., 1966). Wells were made on the agar using a sterile cork borer and filled with $100 \mu \mathrm{L} P$. ostreatus organic extract. The plates were incubated accordingly as described previously. Standard strain of E. coli ATCC 25922 was used as control organism for bacterial assays. Bacteria and fungal control wells contained $100 \mu$ of ciprofloxacin and fluconazole, respecttively, at $5 \mu \mathrm{g}$ per well. A well containing $100 \mu \mathrm{l}$ of Tween-20-PBS solution ( $\mathrm{pH}$ 7.2) was generally used as a positive control well in every assay. Growth inhibition was measured as diameters of inhibitory zones in the nearest $0.1 \mathrm{~mm}$.

\section{Minimum inhibitory concentration (MIC)}

The MICs of the organic extracts were determined by broth dilution method according to Alade and Irobi (1993) with a little modification. The extract was serially diluted with normal saline $(0.85 \mathrm{~g} / \mathrm{dl})$ to $5-50 \mathrm{mg} / \mathrm{ml}$ preparations dispensed $(1.0 \mathrm{ml})$ into test tubes containing $1.0 \mathrm{ml}$ of nutrient or potato dextrose broth. Each sensitive bacterial or fungal isolate $\left(100 \mu \mathrm{l}\right.$ of $\left.10^{8} \mathrm{cfu} / \mathrm{ml}\right)$ was inoculated into the test tubes. The tubes were mixed, covered with cotton wool and incubated appropriately as previously described. Thereafter, the tubes were then examined for microbial growth. The MIC was defined as the minimum concentration of the extract that did not allow any visible growth or turbidity of the organism in broth. MIC $_{50}$ refers to concentration (\%) of $P$. ostreatus required to prevent the growth of $50 \%$ of organisms tested. While $\mathrm{MIC}_{90}$ oil extract concentration, which inhibits the growth of $90 \%$ of the organisms tested.

\section{RESULTS}

The present study has revealed the antibacterial and antifungal activity of petroleum - ether (PE) and acetone
(AE) extracts of $P$. ostreatus fruiting body against multi drug resistant bacterial pathogens presented in Table 1. Data presented in Table 2 showed the fruiting body wet and dry weights per $P$. ostreatus strain analyzed ranged from $1.18-1.37 \mathrm{~g}$ (mean weight $1.27 \pm 0.038 \mathrm{~g}$ ) and $0.126-0.174 \mathrm{~g}$ (mean weight $0.152 \pm 0.0025 \mathrm{~g}$ ), respecttively. The petroleum and acetone extract yields ranged from $3.32-3.40 \mathrm{mg} / \mathrm{g}$ dry mycelial weight yielding an average of $3.36 \pm 0.01 \mathrm{mg} / \mathrm{g}$ dry weight.

Phytochemical analysis revealed the presence of terpenoids, tannins, steroidal glycosides and carbohydrates in both extracts but with higher terpenoids contents in the PE fraction. Cyanogenic glycosides, alkaloids, flavonoids and anthraquinones were not detected in both extracts. Total phenol contents of 325.7 and $352.8 \mathrm{mg} / \mathrm{L} \mathrm{GAE}$ were elicited by $P E$ and $A E$ extracts, respectively, and were further found to be significantly $(P<0.05)$ lower than $1005.3 \mathrm{mg} / \mathrm{L}$ GAE $(P<0.05)$ in the green tea infusion used as standard (Figure 1).

Preliminary antimicrobial testing of petroleum ether extract of $P$. ostreatus by agar-well diffusion produced zones of growth inhibition of $3.0-7.8 \pm(0.1-0.9) \mathrm{mm}$ for the gram positive bacteria, $5.0-8.2 \pm(0.1-0.7) \mathrm{mm}$ for the gram negative bacteria and $8.1-10.8 \pm(0.1-1.6) \mathrm{mm}$ for the fungal isolates tested (Table 3 ). Among the susceptible gram-negative bacteria tested, inhibitory zones due to petroleum extract were higher than those of the acetone extract.

Among the gram-positive bacteria tested, local isolates of $L$. acidophilus ( 2 of 8 ) and $B$. subtilis ( 5 of 5 ) were observed to be the least [3.0-3.2 $\pm(0.1-0.2) \mathrm{mm}]$ and most [7.6 - $7.8 \pm(0.2-0.8) \mathrm{mm}$ ] sensitive strains in both organic extracts. In gram-negative bacteria, local isolates of $E$. 
Table 2. Oil yield and phytochemical analysis of extracts of Pleurotus ostreatus mycelium.

\begin{tabular}{|l|c|c|}
\hline \multicolumn{1}{|c|}{ Parameter } & Amount \\
\hline Fruiting body wet weight (g) / strain & $1.18-1.37(1.27 \pm 0.038)$ \\
Fruiting body dry weight (g) / strain & $0.126-0.174(0.152 \pm 0.0025)$ \\
Extract yield (mg/g dry weight) & $3.32-3.40(3.36 \pm 0.01)$ \\
\hline Phytoconstituents & PE & AE \\
\hline \multicolumn{2}{||}{$\mid$} \\
\hline Terpenoids & \pm \pm & \pm \\
Tanins & \pm & \pm \\
Steroidal glycosides & \pm & \pm \\
Carbohydrates & \pm & \pm \\
Cyanogenic glycosides & - & - \\
\hline
\end{tabular}

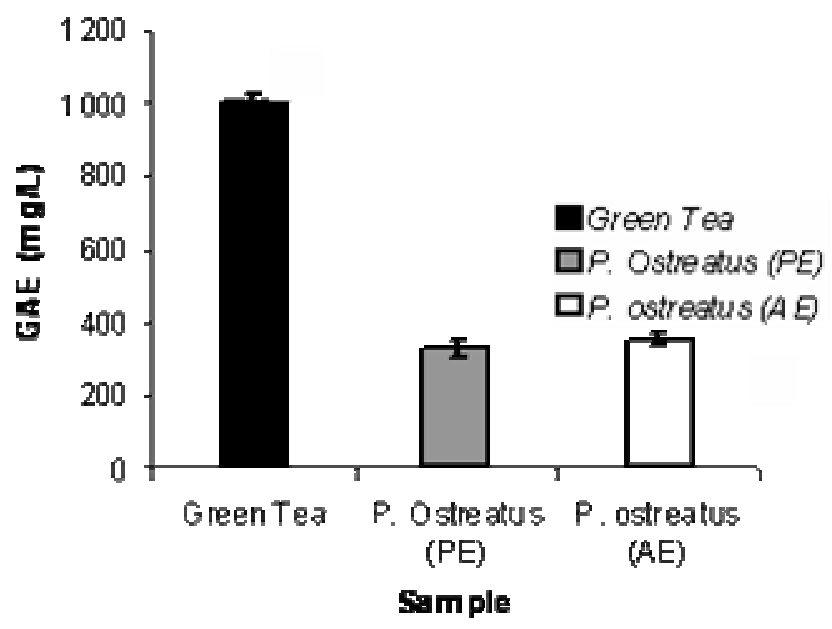

Figure 1. Total phenolic content of Pleurotus ostreatus extracts compared to green tea. $\mathrm{AE}=$ acetone extract; $\mathrm{PE}=$ petroleum ether extract.

coli and $H$. influenzae exhibited the highest $[7.6-8.2 \pm$ $(0.7-0.8) \mathrm{mm}]$ and lowest [5.0 - $5.5 \pm(0.5-0.7) \mathrm{mm}]$ susceptibilities, respectively. Furthermore, highest susceptibility [10.5 - $10.8 \pm(1.2-1.6) \mathrm{mm}]$ by $S$. cerevisiae strains (4 of 4) and lowest susceptibility [8.0-8.1 $\pm(0.1-0.3) \mathrm{mm}]$ by $C$. albicans ATCC1880 were observed among the fungal isolates. On the whole, $79(89.8 \%)$ of the 88 isolates tested showed sensitivity to acetone and petroleum ether extracts of $P$. ostreatus (Table 3 ).

The petroleum ether extract of $P$. ostreatus further showed stronger inhibition of these organisms in broth compared to the acetone extract (results not shown) with MICs of $78.3-100.0 \pm(0-4.1) \%$ extract for gram positive bacteria with Staphylococcus $\mathrm{sp}$. having mean $\mathrm{MIC}_{50}$ and $\mathrm{MIC}_{90}$ of $71.7 \pm 2.9$ and $79.2 \pm 8.8 \%$, respectively. The two sensitive $L$. acidophilus were inhibited with $\mathrm{MIC}_{90}$ of $100 \%$ extract, equivalent to the MIC (Table 4). The inhibition of gram-negative bacteria: $S$. typhi and E. coli by PE was observed at lower MICs (72.5 - 75.0\%), $\mathrm{MIC}_{50}$ $(66.3-67.5 \%)$ and $\mathrm{MIC}_{90}(71.3-72.5 \%)$. The PE also caused growth inhibition of the fungal isolates tested in potato dextrose medium with MICs of $70.0 \pm 3.5 \%$ and $67.5 \pm 3.4 \%$ for Candida sp. and S. cerevisiae, respectively (Table 4).

Antioxidant activty of the extracts by DPPH and ABTS methods revealed a disparate VCEACs of $3.6-3.8 \mathrm{mM}$ for $P E$ and $4.1-4.4 \mathrm{mM}$ for $A E(P>0.05)$ compared to $6.2-6.4 \mathrm{mM}$ in the green tea infuson $(P<0.05)$ (Figure 2).

\section{DISCUSSION}

$P$. ostreatus, an oyster mushroom is primarily consumed for its nutritive value and used industrially as a bioremediator (Solomko and Eliseeva, 1988; Fountoulakis et al., 2002; Tsioulpas et al., 2002). The present study has further revealed the antimicrobial potency of the oil of the macrofungus extracted with petroleum ether and acetone. Both extracts were observed to inhibit gram positive and gram-negative bacteria as well as fungi tested in vitro to suggest that $P$. ostreatus has a broad-spectrum antibacterial and antifungal activity. Similar antimicrobial potentials have been observed in the culture extracts of Irpex lacteus (Rosa et al., 2003) Agrocybe sp. (Kavanagh et al., 1950; Mavoungou et al., 1987), and juice of $L$. edodes (Kuznetsov et al., 2005). Antimicrobial potencies of the essential oils from mushrooms such as Cuminum cyminum, carum carvi, Coriandum sativum and Foeniculum vulgare have also been reported (lacobellis et al., 2005) with activity against bacterial pathogens such as Pseudomonas, Klebsiella, Salmonella and E. coli as observed for $P$. ostreatus in this study.

The observed disparity in the the susceptibilities of gram-ve bacteria tested with petroleum ether extract eliciting greater effect provides an indication that the organic solvents used have varyning abilities to extract bioactive substances from $P$. ostreatus. This is further evidenced 
Table 3. Preliminary antimicrobial testing of Pleurotus ostreatus extracts. Inhibition zone diameter (mm $\pm \mathrm{SD}$ )

\begin{tabular}{|c|c|c|c|c|}
\hline \multirow[t]{2}{*}{${ }^{\circledR}$ Isolates } & \multicolumn{2}{|c|}{ Pleurotus ostreatus } & \multirow[t]{2}{*}{ Standard drugs ${ }^{\#}$} & \multirow[t]{2}{*}{$0.1 \%(v / v)$ Tween-20 } \\
\hline & PE & $\mathbf{A E}$ & & \\
\hline \multicolumn{5}{|l|}{ Gram - positive bacteria } \\
\hline Staphylococcus aureus ATCC 25923 & $7.5 \pm 0.1$ & $7.6 \pm 0.3$ & $27.5 \pm 0.7$ & $\mathrm{G}$ \\
\hline Staphylococcus aureus (8) & $7.2 \pm 0.9$ & $7.1 \pm 0.7$ & $27.7 \pm 0.9$ & G \\
\hline Staphylococcus aureus (2) & $7.0 \pm 0.8$ & $7.0 \pm 0.6$ & $28.1 \pm 0.4$ & $\mathrm{G}$ \\
\hline Staphylococcus epidermidis (4) & $7.1 \pm 0.8$ & $7.0 \pm 0.7$ & $29.1 \pm 0.5$ & $\mathrm{G}$ \\
\hline Bacillus subtilis ATCC 6633 & $7.1 \pm 0.1$ & $7.2 \pm 0.2$ & $27.8 \pm 0.3$ & $\mathrm{G}$ \\
\hline Bacillus subtillis (5) & $7.8 \pm 0.2$ & $7.6 \pm 0.8$ & $28.4 \pm 0.6$ & G \\
\hline Bacillus licheniformis (10) & $7.7 \pm 0.2$ & $7.7 \pm 0.4$ & $27.8 \pm 0.4$ & $\mathrm{G}$ \\
\hline †Lactobacillus acidophilus (2) & $3.0 \pm 0.2$ & $3.2 \pm 0.1$ & $28.9 \pm 0.4$ & $\mathrm{G}$ \\
\hline \multicolumn{5}{|l|}{ Gram -negative bacteria } \\
\hline Salmonella typhi ATCC 13391 & $7.5 \pm 0.1$ & $7.2 \pm 0.4$ & $28.1 \pm 0.1$ & $\mathrm{G}$ \\
\hline Salmonella typhi (5) & $7.2 \pm 0.3$ & $7.0 \pm 0.1$ & $28.4 \pm 1.3$ & $\mathrm{G}$ \\
\hline Escherichia coli ATCC25922 & $7.0 \pm 0.0$ & $7.0 \pm 0.0$ & $29.5 \pm 0.1$ & $\mathrm{G}$ \\
\hline Escherichia coli (10) & $8.2 \pm 0.7$ & $7.6 \pm 0.8$ & $28.5 \pm 1.0$ & G \\
\hline Proteus sp. (3) & $6.9 \pm 0.5$ & $6.5 \pm 0.6$ & $27.8 \pm 0.7$ & $\mathrm{G}$ \\
\hline Klebsiella pneumoniae (4) & $7.1 \pm 0.2$ & $7.0 \pm 0.1$ & $28.0 \pm 0.1$ & $\mathrm{G}$ \\
\hline t†Pseudomonas aeruginosa (3) & $5.6 \pm 0.4$ & $5.2 \pm 0.2$ & $28.2 \pm 0.6$ & G \\
\hline Haemophillus influenzae (4) & $5.5 \pm 0.5$ & $5.0 \pm 0.7$ & $27.7 \pm 0.9$ & $\mathrm{G}$ \\
\hline \multicolumn{5}{|l|}{ Fungi isolates } \\
\hline Candida albicans ATCC 1880 & $8.1 \pm 0.1$ & $8.0 \pm 0.3$ & $28.4 \pm 0.0$ & $\mathrm{G}$ \\
\hline Candida sp. (10) & $8.2 \pm 0.3$ & $8.3 \pm 0.1$ & $28.2 \pm 0.7$ & G \\
\hline Saccharomyces cerevisiae (4) & $10.8 \pm 1.2$ & $10.5 \pm 1.6$ & $28.8 \pm 0.6$ & $\mathrm{G}$ \\
\hline
\end{tabular}

Figures in parentheses represent the number of isolates tested; $\dagger$ All and two of the tested $L$. acidophilus strains were sensitive to ciprofloxacin and $P$. ostreatus, respectively. $t+$ Three (3) of the ciprofloxacin sensitive Pseudomonas aeruginosa isolates (6 Of 6) were also sensitive to $P$. ostreatus. $G=$ Bacterial growth around the in phosphate buffered $0.1 \%$ Tween-20 control wells;

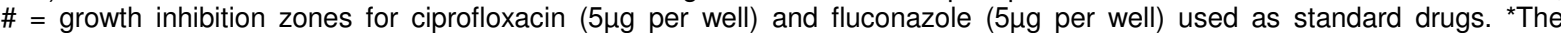
diameters of zone of inhibition were expressed in millimeter $(\mathrm{mm})$ as mean \pm standard deviation. ${ }^{@}$ Seventy-nine $(89.8 \%)$ of the 88 isolates showed sensitivity to $P$. ostreatus. $\mathrm{PE}=$ Petroleum ether extract; $\mathrm{AE}=$ Acetone extract.

Table 4. Minimum inhibitory concentrations determinations of Pleurotus ostreatus petroleum ether extract against multidrug resistant bacteria and yeasts.

\begin{tabular}{|c|c|c|c|}
\hline \multirow[t]{2}{*}{ Isolates } & \multicolumn{2}{|c|}{ MIC (\% extract) } & \multirow[t]{2}{*}{ MIC } \\
\hline & $\mathrm{MIC}_{50}$ & $\mathrm{MIC}_{90}$ & \\
\hline \multicolumn{4}{|l|}{ Gram - positive bacteria } \\
\hline Staphylococcus aureus (15) & $71.7 \pm 2.9$ & $79.2 \pm 8.8^{\mathrm{a}}$ & $80.3 \pm 4.1^{a}$ \\
\hline Bacillus sp. (16) & $70.8 \pm 5.2$ & $74.5 \pm 4.3$ & $78.3 \pm 3.8^{a b}$ \\
\hline Lactobacillus acidophilus (2) & ND & $100.0 \pm 0.0$ & $100.0 \pm 0.0$ \\
\hline \multicolumn{4}{|l|}{ Gram -negative bacteria } \\
\hline Salmonella typhi (10) & $66.3 \pm 4.8$ & $72.5 \pm 6.5^{\mathrm{a}}$ & $75.0 \pm 5.1^{\mathrm{a}}$ \\
\hline Escherichia coli (15) & $67.5 \pm 2.9$ & $71.3 \pm 7.5$ & $71.3 \pm 7.5$ \\
\hline Proteus sp. & $83.8 \pm 4.8$ & $90.1 \pm 4.1^{\mathrm{a}}$ & $92.6 \pm 4.4^{\mathrm{a}}$ \\
\hline Pseudomonas aeruginosa (3) & $91.7 \pm 2.9$ & $100.0 \pm 0.0^{\mathrm{a}}$ & $100.0 \pm 0.0^{\mathrm{a}}$ \\
\hline Klebsiella pneumoniaa (4) & $75.0 \pm 4.1$ & $80.0 \pm 4.1 \mathrm{a}$ & $88.6 \pm 2.6^{\mathrm{ab}}$ \\
\hline Haemophillus influenzae (2) & $88.1 \pm 2.4$ & $95.0 \pm 4.1$ & $100.0 \pm 0.0^{\mathrm{a}}$ \\
\hline Fungi isolates Candida sp. (10) & $65.0 \pm 5.0$ & $70.0 \pm 3.5^{\mathrm{a}}$ & $70.0 \pm 3.5^{\mathrm{a}}$ \\
\hline Saccharomyces cereviciase (4) & $62.7 \pm 3.8$ & $65.0 \pm 4.2$ & $67.5 \pm 3.4^{\mathrm{a}}$ \\
\hline
\end{tabular}

Data are presented as mean \pm SD of experiments in duplicates. Figures in parenthneses indicate the number of isolates tested. in duplicates. Disparity between mean values was analyzed by student's t- test. ${ }^{a} \mathrm{P}<0.05$ ( $\mathrm{MIC}_{50} \mathrm{Vs}_{\text {. }} \mathrm{MIC}_{90}$ or $\mathrm{MIC}) ;{ }^{\mathrm{b}} \mathrm{P}<0.05$ ( $\mathrm{MIC}_{90}$ vs. MIC); $\mathrm{P}<0.05$ = Significant). 


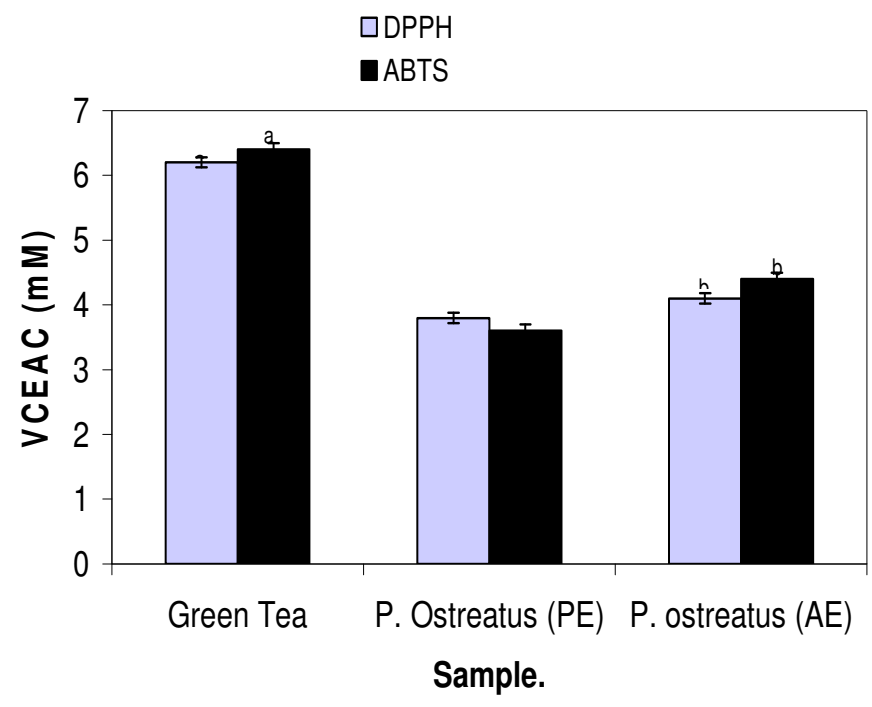

Figure 2. Antioxidant capacity of $P$. ostreatus extracts compared to green tea. Data are mean \pm SEM of 3 determinations; $A E$ and $\mathrm{PE}=$ Acetone and petroleum ether extract, respectively. ${ }^{\mathrm{a}} \mathrm{P}<$ 0.05 (Green tea vs $P$. ostreatus) ${ }^{\mathrm{b}} \mathrm{P}>0.05$ ( $P$. ostreatus $-\mathrm{AE}$ vs $P E)$.

by the different levels of terpenoids and phenolics observed in the two organic extracts. A clue that the petroleum extract may have greater antibacterial potential was provided by the observed $\mathrm{MIC}_{50}$ and $\mathrm{MIC}_{90}$ inhibitory concentrations of the extract against $S$. aureus, $S$. typhi and Candida isolates tested. Similar antibacterial characteristics have been observed in fluoroquinolones such as ciprofloxacin (Iwalokun et al., 2001) and medicinal plants such as Ocimum gratissimum (Iwalokun et al., 2003). Meanwhile, terpenoids have been implicated as the phytoconstituents responsible for the antibacterial activity of mushrooms including Cuminum cyminum and Carum carvi (lacobellis et al., 2005). The observed phenolic and tannin conctituents of $P$. ostreatus may also elicit antibacterial activity as found in many medicinal plants with mechanisms of action characterized by cell membrane lysis, inhibition of protein synthesis, proteolytic enzymes and micriobial adhensins (Cowan, 1999).

However, the observed insensitivity of 6 of 8 L. acidophilus and 3 of $6 P$. aeruginosa isolates tested to $P$. ostreatus extracts implies that strain variation may determine susceptibility of bacteria to antibacterial agents from mushrooms. A recent study by Kuznetzov et al. (2005) also revealed the insensitivity of Bifidobacteria and Lactobacilli to the antibacterial action of $L$. edodes juice. However, the observed inhibition of the $S$. cerevisiae strains tested by $P$. ostreatus agrees with the findings of Hwang et al. (2000) in which Phellinus sp. were found to halt the growth of $S$. cerevevisiae with an $\mathrm{IC}_{50}$ value of $76 \square \mathrm{g} / \mathrm{ml}$ via chitin synthase inhibition. These observations may confer ecological and metabolic benefits to edible mushrooms since lactic acid bacteria may act synergistically to improve the nutritional quality and shelf life of associated fermented foods (Okamura-Matsui et al., 2001) and yeast contamination has been implicated in the decay of mushrooms (Middlelhoven, 2004). However, the observed growth inhibition halos $(5.5-10.1 \mathrm{~mm})$ produced by $P$. ostreatus were lower than $>12.0 \mathrm{~mm}$ halos produced by $I$. lateus as reported by Rosa et al. (2003) but comparable to halos produced by Agaricus sp., Gloedoporus thelephoroides and Coprinus sp. reported by the same workers.

The reported variations in the antimicrobial outcomes of these macrofungus may not be unconnected with their species and strain variations, differences in their microbicidal composition and concentrations, in the method of extraction and mechanism of actions of active principles in these edible mushrooms. Antibacterial agents such as agrobycin from Agrocybe sp (Kavanagh et al., 1950) and marasmic acid from Marasmius conigenus have been observed to elicit activity at microgram per ml concentrations. Guo et al. (2005) recently isolated trichogin, an antifungal protein from Tricholoma giganteum and found the protein exhibiting HIV-1 reverse transcriptase inhibition with an $\mathrm{IC}_{50}$ of $83 \mathrm{nM}$.

Other bioactive antimicrobial compounds that have also been isolated from edible basidiomycetes include glaucopines from Sarcodon glaucopus, pleuromutilin and chanterellins from chanterelle mushrooms (Curini et al., 2005; Kavanagh et al., 1950).

These substances masquerade as phenolics and terpenoids (Mothana et al., 2000), which were also detected in $P$. ostreatus. Therefore, there is no doubt that the future determination of the structure and functions of the phenolic and terpenoid constituents of $P$. ostreatus would further validate its antimicrobial potentials.

The present study also observed $P$. ostreatus to elicit antioxidant capacity using the DPPH and ABTS methods thereby expanding its nutraceutical values. However, the observed VCEAC (3.6 - 4.4 mM) for $P$. ostreatus is lower than values reported for some selected Indian medicinal mushrooms including G. Iucidum by Lakshmi (2004) and Button mushrooms by Miller et al. (2000) with antioxidant capacity mostly attributed to their phenolic contents, the antioxidant properties of polysaccharide and polysaccharide peptides of $G$. lucidum being an exception (You and Lin, 2003). However, the observed higher phenolic contents and antioxidant capacity in the acetone extract of $P$. ostreatus compared to the petroleum extract provides an indication for a superiority of acetone over petroleum ether in the exudation of antioxidant substances from $P$. ostreatus.

Flavonoids, which are also phenolic compounds with antioxidant activity (Mau et al., 2002; Gil et al., 2000) were not detected in $P$ ostreatus. Our observation agrees with findings of Mattila et al. (2001) and according to USDA, mushrooms are regarded as non-sources of flavonoids. The absence of flavonoids in mushrooms may be of biological advantage in their various ecological nic- 
hes since these bioactive compounds inhibit enzyme activities (e.g. tyrosinase) involved in their pigmentation, growth and development (Xie et al., 2003).

The low and varied phenolic contents of $P$. ostreatus, could also emanate from the differences in the mycelial wet and wet weights of the tested in this study. This may be attributed to the variations in their growth conditions since they were not cultivated in the same location. The works of Nwanze et al. (2005a, 2005b) on Lentinus squarrosulus and Psathyrella atroumbonata showed that both media composition and oil type influence the mycelial biomass of these mushrooms. Therefore, appreciable amount of extract and thus phenolic compounds and terpenoids can be recovered from $P$. ostreatus if its optimum growth condition is known. This may further enhance its medicinal and market values.

Based on the results of this study, it can be concluded $P$. ostreatus, an edible oyster mushroom has antioxidant potentials and possess a broad-spectrum antibacterial and antifungal activity, optimisable by multiple organic mycelia extraction. Further investigations that would identify the active phenolic and terpenoid compounds and determine the optimal mycelial growth conditions of $P$. ostratus are necessary.

\section{REFERENCES}

Acharya K, Yonzone P, Rai M, Rupa A (2005). Antioxidant and nitric oxide synthase activation properties of Ganoderma applanatum. Indian. J. Exp. Biol. 43: 926-929.

Akpata ES, Akinrinmisi EO (1977). Antibacterial acticity of extracts of some African chewing sticks. Hos Surg, 44: 717-722.

Alade PI, Irobi ON (1993). Antimicrobial activities of crude extract of Acalypha wilkesiana. J. Erthnopharmacol. 39: 171-174.

Bauer AW, Kirby WMM, Sherris JC, Truck M (1966). Antibiotic susceptibility testing by a standar single dose method. Am. J. Clin Pathol. 45: 493-496.

Brand-Williams W, Cuvelier ME, Berset C (1995). Use of a free radical method to evaluate antioxidant activity. Lebensm. Wiss. Technol 28: 25-30.

Bobek P. Galbavy S (1999). Hypocholesteremic and antiatherogenic effect of oyster mushroom (Pleurotus ostreatus) in rabbits Nahrung 43: 339-342.

Cano A, Hernandez-Ruiz J, Garcia-Carnovas F, Acosta M, Arnao MB (1998). An end-point method for estimation of the total antioxidant activity in plant material. Phytochem. Anal. 9: 196-202.

Cao G, Sofic E, Prior RL (1996). Antioxidant capacity of tea and common vegetables. J. Agric. Food. Chem, 44: 3426-3431.

Chang ST, Miles PG (1992). Mushrooms biology-a new discipline Mycologist 6: 64-5.

Cowan MM (1999). Plant products as antimicrobial agents. Clin. Microbiol. Rev. 12: 564-582.

Cowan ST, Steele KJ (1974). Manual for the identification of medical bacteria. $2^{\text {nd }}$ edition. Cowan. Cambridge University Press.

Cui Y, Kim DS, Park KC (2005). Antioxidant effect of Inonotus obliquus. J. Ethnopharmacol. 96: $79-85$

Curini M, Maltese F, Marcotullio MC, Menghini L, Pagiotti R, Rosati O, Altinier $G$ (2005). Glaucopines A and B, new cyathane diterpenes from the fruiting bodies of Sarcodon glaucopus. Plant Med. 71: 488.

De Mann YC, Rogossa M, Sharpe ME (1960). A method for the cultivation of lactobacilli. J. Appl. Bacteriol. 23: 130-135.

Dikeman CL, Bauer LL, Flickinger EA, Fahey GC Jr. (2005). Effects of stage of maturity and cooking on the chemical composition of select mushroom varieties. J. Agric. Food Chem., 53: 1130-1138.
Fountoulakis MS, Dokianakis SN, Kornaros ME, Aggelis GG, Lyberatos $G$ (2002). Removal of phenolics in olive mill wastewaters using the white-rot fungus Pleurotus ostreatus. Water Res, 36: 4735-4744

Gil MI, Thomas-Baberan FA, Hess-Pierce B, Holcroft DM, Kader AA (2000). Antioxidant activity of pomegranate juice and its relationship with phenolic composition and processing. J. Agric. Food. Chem., 48: 4581-4589

Guo Y, Wang H, Ng TB (2005). Isolation of trichogin, an antifungal protein from fresh fruiting bodies of the edible mushroom Tricholoma giganteum. Peptide. 26: 575-580.

Harbone JB (1973). Phytochemical methods. London. Chapman and Hall. Ltd. pp. 49-188.

Hwang El, Yun BS, Kim YK, Kwon BM, Kim HG, Lee HB, Jeong W, Kim SU (2000). Phellinsin A, a novel chitin synthase inhibitor produced by Phellinus sp. PL3. J. Antibiot, 53: 448-450.

lacobellis NS, Lo Cantore P, Capasso F, Senatore F (2005). Antibacterial activity of Cuminum cyminum L. and Carum carvi L. essential oils. J. Agric. Food Chem. 53: 57-61.

Iwalokun BA, Gbenle GO, Adewole TA, Smith SI, Akinsinde KA (2003). Effects of Ocimum gratissimum leaf oil at subinhibitory concentrations on virulent and multidrug resistant Shigella strains from Lagos, Nigeria. APMIS 111: 477-482.

Iwalokun BA, Gbenle GO, Smith SI, Ogunledun A, Akinsinde KA, Omonigbehin EA (2001). Epidemiology of shigellosis in Lagos, Nigeria: Trends in antimicrobial resistance. J. Health. Popul. Nutr. 19: 183190.

Iwalokun BA, Ogunledun A, Ogbolu DO, Bamiro SB, Jimi-Omojola J (2004). In vitro Antimicrobial Properties of Aqueous Garlic Extract Against Multidrug-Resistant Bacteria and Candida Species from Nigeria. J. Med. Food, 7: 327-333.

Kavanagh F, Hervey A, Robbins WJ (1950). Antibiotic substances from basidiomycetes. VI. Agrocybe dura. Proc. Natl. Acad. Sci. USA 36: 102-106.

Kuznetsov OIU, Mil'kova EV, Sosnina AE, Sotnikova NIU (2005). Antimicrobial action of Lentinus edodes juice on human microflora $\mathrm{Zh}$ Mikrobiol. Epidemiol. Immunobiol. 1: 80-82.

Lakshmi B, Tilak JC, Adhikari S, Devasayagam TPA, Janardhanan KK (2004). Evaluation of antioxidant activity of selected Indian mushrooms. Pharmaceutic. Biol. 42: $179-185$.

Lee KI, Kim YJ, Lee HJ, Lee CY (2001). Cocoa has more phenolic phytochemicals ands a highert antioxidant capacity than teas and red wine. J. Agric. Food. Chem, 51: 7292-7295.

Lindequist U, Niedermeyer THJ, Julich W (2005). The pharmacological potentials of mushrooms. eCAM, 2: 285-299.

Mattila P, Konko K, Eurola M, Pihlava JM, Astola J, Vahteristo L, Hietaniemi V, Kumpulainen J, Valtonen M, Piironen V (2001). Contents of vitamins, mineral elements, and some phenolic compounds in cultivated mushrooms. J. Agric. Food Chem. 49: 2343-2348.

Mau JL, Lin HC, Chen CC (2002). Antioxidant properties of several medicinal mushrooms. J. Agric. Food Chem., 50: 6072-6077.

Mavoungou H, Porte M, Oddoux L (1987). Active antitumoraled des myceliums d'Agrocybe dura, Mycoacia uda et Phanerochaete laevis. Ann. Pharmaceutic. Francaises, 45: 71-77.

Middelhoven WJ (2004). The yeast flora of some decaying mushrooms on trunks of living trees. Folia Microbiol (Praha), 49: 569-573.

Miller HE, Rigelhorf R, Marquart L, Prakash A, Kanter M (2000). Antioxidant of whole grain breakfast cereals, fruits and vegetables. J. Am. Col. Nutr. 19: 312S-319S.

Mothana RAA, Jansen R, Jülich WD, Lindequist U (2000). Ganomycin A and $B$, new antimicrobial farnesyl hydroquinones from the basidiomycete Ganoderma pfeifferi J. Nat. Prod. 63: 416-418.

Nwanze PI, Khan AU, Ameh JB, Umoh VJ (2005a). The effect of media, oil type and rate on the mycelia wet and dry weights of Lentinus squarrosulus (Mont.) singer and Psathyrella atroumbonata Pegler in submerged liquid culture. Afr. J. Biotechnol. 4: 326-331.

Nwanze PI, Khan AU, Ameh JB, Umoh VJ (2005b). The effects of interaction of various oil types and rates on the mycelia wet and dry weights of Lentinus squarrosulus (Mont.) singer and Psathyrella atroumbonata Pegler in submerged liquid culture. Afr. J. Biotechnol 4: 620-626.

Okamura-Matsui T, Takemura K, Sera M, Takeno T, Noda H, Fukuda S, 
Ohsugi M (2001). Characteristics of a cheese-like food produced by fermentation of the mushroom Schizophyllum commune. J Biosci Bioeng., 92: 30-32.

Rosa LH, Machado KMG, Jacob CC, Capelkari M, Rosa CA, Zani CL (2003). Screening of Brazillian basidiomycetes for antimicrobial activity. Mem. Inst. Oswaldo. Cruz, 98: 1-19.

Sofowora A (1993). Medicinal plants and Traditional medicine in Africa. Spectrum Books. Ltd. Ibadan, Nigeria. pp. 270-289.

Solomko EF, Eliseeva GS (1988). Biosynthesis of vitamins B by the fungus Pleurotus ostreatus in a submerged culture. Prikl Biokhim Mikrobiol, 24: 164-169.

Stamets P. 2000. Growing Gourmet and Medicinal Mushrooms. Berkely Ten Speed Press.

Trease G, Evans WC (1989). Pharmacognosy. $11^{\text {th }}$ edn. Brailliar Tiridel. Can. Macmillian.publishers.
Tsioulpas A, Dimou D, Iconomou D, Aggelis G (2002). Phenolic removal in olive oil mill wastewater by strains of Pleurotus spp. in respect to their phenol oxidase (laccase) activity. Biores. Technol, 84: 251-257.

Valentao P, Andrade PB, Rangel J, Ribeiro B, Silva BM, Baptista P, Seabra RM (2005). Effect of the conservation procedure on the contents of phenolic compounds and organic acids in chanterelle (Cantharellus cibarius) mushroom. J. Agric. Food Chem. 53: 49254931.

Xie LP, Chen OX, Huang H, Wang HZ, Zhang RQ (2003). Inhibitory effects of some flavonoids on the activity of mushroom tyrosinase. Biochemistry (Mosc), 68: 487-491.

You YH, Lin ZB (2003). Antioxidant effect of Ganoderma polysaccharide peptide. Yao Xue Xue Bao, 38: 85-88. 